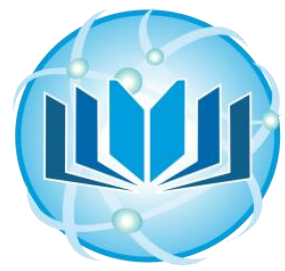

\title{
Antioxidant Properties of Plant Extracts
}

\section{Raymond C Jagessar*}

Affiliation: Department of Chemistry, Faculty of Natural Sciences, University of Guyana, Guyana.

${ }^{*}$ Corresponding author: Jagessar RC, Department of Chemistry, Faculty of Natural Sciences, University of Guyana (USTC), Georgetown, Guyana, Email: raymondjagessar@yahoo.com

Citation: Jagessar RC. Antioxidant properties of plant extracts (2019) Edelweiss Pharma Analy Acta 1: 18-21.

Received: Oct 11, 2019

Accepted: Nov 13, 2019

Published: Nov 19, 2019

Copyright: () 2019 Jaggesar RC. This is an open-access article distributed under the terms of the Creative Commons Attribution License, which permits unrestricted use, distribution, and reproduction in any medium, provided the original author and source are credited.

\begin{abstract}
There is a continued interest to screen plant extracts for their antioxidant properties, in light of the fact that antioxidant activities parallel anticancer activities, amongst their ability to combat other diseases. Cancer is one of the diseases that has a high mortality status in developed countries and is on the rise in developing countries. Plant extracts have been tested for their antimicrobial, anticancer, Antidiabetic, insect repellant and a range of other biological activities. Since 1990s, antioxidant research has expanded significantly, due to its potential benefits in disease prevention and health promotion. Guyana, a country located on the mainland of South America and whose rich diverse flora needs continual screening for plants with a range of pharmaceutical and medicinal activities of which, antioxidant is one. In addition, the isolation of known and unknown natural antioxidants may contribute to novel drug discovery. This article is a mini review of plants/plant extracts that have exhibited antioxidant properties.
\end{abstract}

Keywords: Screen plant extracts, Antioxidant activities, Anticancer activities, Antidiabetic activities.

\section{Introduction}

Antioxidants are chemical compounds or mixture of compounds, which when present in low concentrations are used to prevent the oxidation of lipids, sugars and proteins and DNA that can generate aldehydes, ketones, esters and other products that can be harmful to living systems. Antioxidants can be synthetic or natural. Synthetic antioxidants include Butylated Hydroxyl Anisole (BHA), Butylated Hydroxyl Toluene (BHT), Tert-Butyl Hydroquinone (TBHQ) and Propyl Gallate (PG) etc [1]. Natural antioxidants are those that can be obtained from fruits, vegetables and plant extracts. There is an increasing interest to use plant extracts as antioxidant agents.

Table 1 shows some plants that have rich antioxidant profile, whereas Table 2 shows the chemical constituents of some antioxidant plants. Natural antioxidants may function (a) as reducing agents, (b) as free radical scavengers, (c) as complexers of pro-oxidant metals, and (d) as quenchers of the formation of singlet oxygen. However, the major value is in their primary antioxidant activity as free radical acceptors and as chain breakers. Free radicals are usually produced in normal or pathological cell metabolism. Reactive Oxygen Species (ROS) react with free radicals to become free radicals themselves. ROS include free radicals such as superoxide anion radicals, hydroxyl radicals, non-free radical species and singlet oxygen [2-5].

Excess generation of ROS, induced by various stimuli and which exceed the antioxidant capacity of the organism can lead to various pathophysiological processes such as diabetes, cancer, inflammation, genotoxicity, alzheimers disease and cataracts, retinopathy, rheumatism, skin disease porphyria and senile dementia stroke [6-8]. Antioxidants usually react with reactive free radicals to destroy them by accepting or donating electron(s) to eliminate the radical or they may indirectly decrease the formation of free radicals. Antioxidants also act by forming complexes with metals.
Human cells protect themselves against enzymatic and non-enzymatic antioxidant systems against free radical damage. However, these protective antioxidant mechanisms may not be enough to prevent severe or continued antioxidant stress [9]. Hence, natural or synthetic antioxidants are necessary. In nature, there is a wide variety of natural antioxidants which are different in their chemical composition, physical and chemical properties.

These include enzymes such as Superoxide dismutase, catalase etc. High molecular weight compounds such as protein like albumin, transferrin, ceruplasmin, low molecular weight compounds such as tocopherol, quinines, bilirubin, ascorbic acid, uric acid etc. Minerals such as selenium, copper, manganese, zinc etc. Vitamins such as vitamin $\mathrm{A}, \mathrm{C}$ and $\mathrm{E}$ and plant antioxidants. Also the flavonoids (flavanols, isoflavones, flavones, catchins, flavanones), cinnamic acid derivatives, coumarins, tocopherols, and polyfunctional organic acids. Some of these are shown in Figure 1 Screening of plants for antioxidant activities can be established via various in vitro methods such as DPPH, Nitric oxide method, DMPD, ABTS, ORAC, TBARS assays [1-8], [20-25] etc.

Guyana has a richly biodiversified flora and medicinal studies such as antimicrobial [10-18], antidiabetic [19] have received increasing attention. However, there are few unpublished work on antioxidant and anticancer activities. It's highly imperative that research proliferate with regards to anticancer and antioxidant activities as there are an alarming increase in the deadly cancer disease worldwide and in Guyana. Plant parts such as stems, leaves and fruits rich in antioxidant properties are good in combat against cancer. Also, the chromatographic purification of the crude plant extracts from the Guyanese flora can lead to known and unknown natural products, whose antioxidants properties can be investigated and compared with the crude plant extracts. This forms the basis for novel antioxidant drugs discovery. 
Few researches in Guyana have done on the isolation of natural products from plants of the Guyanese flora. The isolation of natural products from Montricardia arborescens and Passiflora edulis, two plants from the Guyanese flora, suspected to have antioxidant properties has been pursued. Table 3 shows some plants with suspected antioxidant properties, based on folklore from the flora of Guyana. There chemical constituents needs investigation.

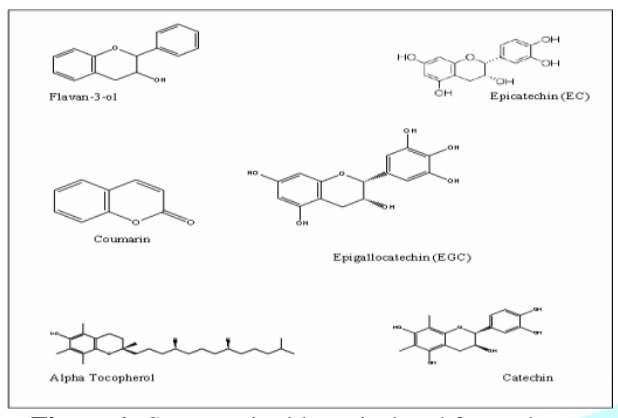

Figure 1: Some antioxidants isolated from plants.

\begin{tabular}{|c|c|c|c|}
\hline & Name of Plants & Family & Part used \\
\hline 1 & Allium sativum Linn & Lilaceae & Bulb \\
\hline 2 & Asparagus racemosus Willd & Lilaceae & shoot \\
\hline 3 & Baccharis cordifolia DC & Asteraceae & Aerial parts \\
\hline 4 & Bryonia alba Linn & Cucurbitaceae & Root \\
\hline 5 & Cichorium intybus Linn & Asteraceae & leaf \\
\hline 6 & Cinnamomum zeylanicum Breyn & Lauraceae & Bark \\
\hline 7 & Crithmum maritimum Linn & Apiaceae & $\begin{array}{l}\text { Essential } \\
\text { Oil }\end{array}$ \\
\hline 8 & Cynara scolymus Linn & Asteraceae & Leaf \\
\hline 9 & Emilia sonchifolia $D C$ & Asteraceae & leaf \\
\hline 10 & $\begin{array}{l}\text { Eucalyptus camaldulensis Dehnh. } \\
\text { syn }\end{array}$ & Myrtaceae & leaf \\
\hline 11 & Eucommia ulmoides Oliver & Eucommiaceae & leaf \\
\hline 12 & Garcinia kola Heckel & Clusiaceae & fruit \\
\hline 13 & Ginkgo biloba Linn & Ginkgoaceae & leaf \\
\hline 14 & Lavandula angustifolia Mill & Lamiaceae & Aerial parts \\
\hline 15 & Lycium barbarum Linn & Solanaceae & Fruit \\
\hline 16 & Melissa officinalis Linn & Lamiaceae & Aerial parts \\
\hline 17 & Murraya koenigii (Linn) Spreng. & Rutaceae & leaf \\
\hline 18 & Myrica gale Linn & Myricaceae & Fruit \\
\hline 19 & Panax ginseng Mey & Araliaceae & Root \\
\hline 20 & Picrorrhiza kurroa Royle ex Benth & Scrophulariaceae & $\begin{array}{c}\text { Rhizome, } \\
\text { Root }\end{array}$ \\
\hline 21 & Piper nigrum Linn & Piperaceae & Fruit \\
\hline 22 & Plantago asiatica Linn & Plantaginaceae & seed \\
\hline 23 & Prunus domestica Linn & Rosaceae & Fruit \\
\hline 24 & Rhazya stricta Decne & Apocyanaceae & leaf \\
\hline 25 & Rosmarinus officinalis Linn & Lamiaceae & Aerial parts \\
\hline 26 & Salvia officinalis Linn & Lamiaceae & Aerial parts \\
\hline 27 & Salvia triloba Linn. $F$. & Lamiaceae & leaf \\
\hline 28 & Solanum melongena Linn & Solanaceae & Fruit \\
\hline 29 & Solanum tuberosum Linn & Solanaceae & Tuber \\
\hline 30 & Syzygium caryophyllatum (Linn) & Myrtaceae & $\begin{array}{c}\text { Flower } \\
\text { buds }\end{array}$ \\
\hline 31 & Thymus zygis Sibth \& Sm & Lamiaceae & Aerial parts \\
\hline 32 & Tinospora cordifolia (Willd) & Menispermaceae & Root \\
\hline 33 & Uncaria tomentosa $D C$ & Rubiaceae & Bark \\
\hline 34 & Zingiber officinale Rosc. & Zingiberaceae & Rhizome \\
\hline
\end{tabular}

Table 1: Some medicinal plants with antioxidants activity.

The antioxidant activities of plant extracts, fruits and vegetables are well documented [1-9], [20-25]. Thirty (30) plants aqueous extracts were investigated for their antioxidant properties via several methods such as DPPH, ABTS radical scavenging capacity assay, Oxygen Radical Absorbance Capacity (ORAC) assay, Superoxide Dismutase (SOD) assay, and Ferric Reducing Antioxidant Potential (FRAP) [20]. In addition, the Total phenolic content was determined by the Folin-Ciocalteu Method, (FCM). Results showed that oak (Quercus robur), pine (Pinus maritima), and cinnamon (Cinnamomum zeylanicum) aqueous extracts possessed the highest antioxidant activities and thus could be potential rich sources of natural antioxidants. A significant relationship existed between antioxidant capacity and total phenolic content, indicating that phenolic compounds are the major contributors to the antioxidant properties of these plants [20].

The antioxidant activities of the methanol extracts from the leaves and stems of Celtis africana (Ulmaceae) were assessed in an effort to validate the medicinal potential of the subterranean part of the herb. The antioxidant activity and phenolic contents of the stem as determined by the DPPH, proanthocyanidins, total phenols, the flavonoids, and total flavonols were higher than that of the leaves [21].

\begin{tabular}{|c|c|c|c|c|}
\hline & $\begin{array}{l}\text { Botanical/ } \\
\text { Family }\end{array}$ & $\begin{array}{c}\text { Common } \\
\text { name }\end{array}$ & $\begin{array}{l}\text { Part } \\
\text { used }\end{array}$ & $\begin{array}{c}\text { Chemical } \\
\text { constituents }\end{array}$ \\
\hline 1 & $\begin{array}{l}\text { Curcuma domestica } \\
\text { Valeton syn. }\end{array}$ & Turmeric & leaf & $\begin{array}{c}\text { Curcumin, b-pinene, } \\
\text { Camphene, eugenol, b- } \\
\text { sitosterol }\end{array}$ \\
\hline 2 & $\begin{array}{c}\text { Cuscuta reflexa } \\
\text { Roxb. } \\
\text { (Convolvulaceae) }\end{array}$ & Akashabela & Stem & $\begin{array}{l}\text { Flavonoids, dulcitol,Bergenin, } \\
\text { coumarins, Glycosides, lactone }\end{array}$ \\
\hline 3 & Daucus carota & Carrot & Root & $\begin{array}{c}\text { Carotenes, carotenoids, } \\
\text { glycosides, flavonoids, sugars, } \\
\text { quaternary bases } \\
\end{array}$ \\
\hline 4 & $\begin{array}{c}\text { Emblica officinalis } \\
\text { Gaertn } \\
\text { (Euphorbiaceae) }\end{array}$ & $\begin{array}{l}\text { Amla/Emblic } \\
\text { Myrobalan }\end{array}$ & Fruit & $\begin{array}{l}\text { Vitamin C (L-ascorbic acid), } \\
\text { polyphenols (ellagic acid, } \\
\text { gallic acid, tannins) }\end{array}$ \\
\hline 5 & $\begin{array}{l}\text { Foeniculum vulgare } \\
\text { Mill }\end{array}$ & Saunf, Fennel & Fruit oil & \\
\hline 6 & $\begin{array}{c}\text { Glycyrrhiza glabra } \\
\text { Linn (Fabaceae) }\end{array}$ & $\begin{array}{c}\text { Mulethi } \\
\text { Liquorice }\end{array}$ & Root & Glycosides \\
\hline 7 & $\begin{array}{l}\text { Mangifera indica } \\
\text { Linn } \\
\text { (Anacardiaceae) }\end{array}$ & Am/Mango & $\begin{array}{l}\text { Root. Leaf, } \\
\text { fruit }\end{array}$ & $\begin{array}{c}\text { Cyanogenetic glycosides, } \\
\text { Polyphenols, vitamin A \& C, } \\
\text { mangiferein, b-sitosterol, } \\
\text { quercetin, ellagic acid, gallic } \\
\text { acid }\end{array}$ \\
\hline 8 & $\begin{array}{c}\text { Momordica } \\
\text { charantia Linn } \\
\text { (Cucurbitaceae) } \\
\end{array}$ & $\begin{array}{l}\text { Karela/Bitter } \\
\text { Melon }\end{array}$ & $\begin{array}{l}\text { Root, leaf, } \\
\text { fruit, seed }\end{array}$ & $\begin{array}{l}\text { Stearic acid, triterpene, } \\
\text { glycosides }\end{array}$ \\
\hline 9 & $\begin{array}{l}\text { Ocimum sanctum } \\
\text { Linn (Lamiaceae) }\end{array}$ & $\begin{array}{l}\text { Tulsi/Sacred } \\
\text { Basil }\end{array}$ & leaf & $\begin{array}{l}\text { Volatile oil, terpenoids, } \\
\text { eugenol, thymol, estragole }\end{array}$ \\
\hline 10 & $\begin{array}{c}\text { Psoralea corylifolia } \\
\text { Linn. (Fabaceae) }\end{array}$ & Babchi & seed & $\begin{array}{c}\text { Essential oil, fixed oil, resin, } \\
\text { bakuchiol (monoterpene } \\
\text { phenol) }\end{array}$ \\
\hline 11 & $\begin{array}{c}\text { Santalum album } \\
\text { Linn (Santalaceae) }\end{array}$ & $\begin{array}{c}\text { Safed } \\
\text { chandan/Sandal }\end{array}$ & $\begin{array}{l}\text { Heartwood } \\
\text {, Bark }\end{array}$ & $\begin{array}{c}\begin{array}{c}\text { Volatile oil,Santalol,-santalol, } \\
\text { b-santalol, b-sitosterol }\end{array} \\
\end{array}$ \\
\hline 12 & $\begin{array}{l}\text { Solanum nigrum } \\
\text { Linn. Solanaceae }\end{array}$ & $\begin{array}{c}\text { Makoi/Commo } \\
\text { n Nightshade }\end{array}$ & Leaf & $\begin{array}{l}\text { Polyphenolic compounds, } \\
\text { Flavonoids, Steroids }\end{array}$ \\
\hline 13 & Swertia chirayita & $\begin{array}{c}\text { Chirayita/ } \\
\text { Chiretta }\end{array}$ & $\begin{array}{l}\text { Whole } \\
\text { plant }\end{array}$ & $\begin{array}{c}\text { Xanthones, mangiferin, } \\
\text { swertinin, chiratin, arginine }\end{array}$ \\
\hline
\end{tabular}

Table 2: Antioxidant plant and chemical constituents.

\begin{tabular}{|c|c|c|c|}
\hline & Botanical/Family name & Common name & Part used \\
\hline 1 & $\begin{array}{c}\text { Abrus precatorious } \\
\text { (Leguminosae) }\end{array}$ & Crab eyes & Leaf and bark \\
\hline 2 & Curcuma domestica Valeton syn. & Turmeric & leaf \\
\hline 3 & Annona muricata (Annonaceae) & Kaiedi Soursop & Leaf and fruit \\
\hline 4 & Artocarpus altilis (Moraceae) & Breadfruit & Leaves and fruit \\
\hline 5 & $\begin{array}{c}\text { Cuscuta reflexa Roxb. } \\
\text { (Convolvulaceae) }\end{array}$ & Akashabela & Stem \\
\hline 6 & Daucus carota & Carrot & Root \\
\hline 7 & $\begin{array}{c}\begin{array}{c}\text { Emblica officinalis Gaertn } \\
\text { (Euphorbiaceae) }\end{array} \\
\end{array}$ & $\begin{array}{c}\text { Amla/Emblic } \\
\text { Myrobalan }\end{array}$ & Fruit \\
\hline 8 & Foeniculum vulgare Mill & Saunf, Fennel & Fruit oil \\
\hline 9 & Syzygium cumini & Jamun & leaf and fruit \\
\hline 10 & $\begin{array}{c}\text { Mangifera indica Linn } \\
\text { (Anacardiaceae) }\end{array}$ & Am/Mango & root. Leaf, fruit \\
\hline 11 & $\begin{array}{c}\text { Momordica charantia Linn } \\
\text { (Cucurbitaceae) }\end{array}$ & Karela/Bitter Melon & $\begin{array}{l}\text { root, leaf, fruit, } \\
\text { seed }\end{array}$ \\
\hline 12 & $\begin{array}{c}\text { Ocimum sanctum Linn } \\
\text { (Lamiaceae) }\end{array}$ & Tulsi/Sacred Basil & leaf \\
\hline 13 & Passiflora edulis & Passion fruit & fruit \\
\hline 14 & pomegranate & (Punica granatum) & fruit \\
\hline 15 & $\begin{array}{l}\text { Solanum nigrum Linn. } \\
\text { Solanaceae }\end{array}$ & $\begin{array}{c}\text { Makoi/Common } \\
\text { Nightshade }\end{array}$ & leaf \\
\hline 16 & Broad leaf Thyme & $\begin{array}{c}\begin{array}{c}\text { Plectranthus } \\
\text { amboinicus }\end{array} \\
\end{array}$ & leaf \\
\hline 17 & Rumex acetosa & Sorrel & fruit \\
\hline 18 & Morinda citrifolia & Yaw-weed & leaves \\
\hline
\end{tabular}

Table 3: Some Antioxidant plants found in Guyana. 
Three plant foods, namely, drumstick leaves (Moringa oleifera), mint leaves (Mentha spicata) and carrot tuber (Daucus carota) ethanolic extracts were analyzed for their antioxidant activity. The antioxidant activity of extracts was evaluated according to the amount of Malonaldehyde (MDA) formed by the $\mathrm{FeSO}_{4}$-induced oxidation of linoleic acid and a high PUFA oil (sunflower oil) at $37{ }^{\circ} \mathrm{C}$ in Trizmabuffer $(\mathrm{pH}$ 7.4). The antioxidant activity of the extracts from mint leaves and carrot was higher at $\mathrm{pH} 9$ than $\mathrm{pH} 4$, while that of drumstick extract remained the same under both $\mathrm{pH}$ conditions [22].

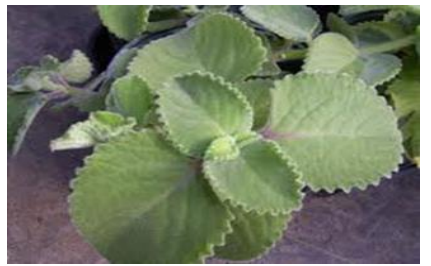

(a)

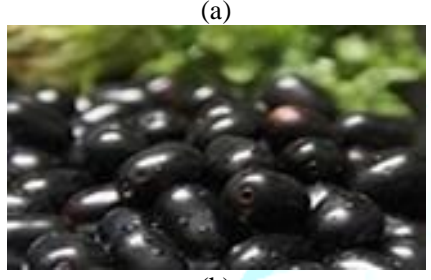

(b)

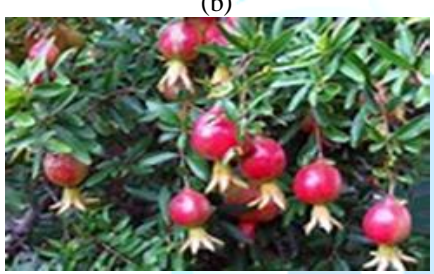

(c)

Figure 2: Pictures of some plant parts from antioxidant plants from the Guyanese flora. (a) Thyme (b) Jamoon (c) Pomergranate.

The antioxidative activity of 92 phenolic extracts from edible and nonedible plant (berries, fruits, vegetables, herbs, cereals, tree materials, plant sprouts, and seeds) was examined by autoxidation of methyl linoleate method [23]. The total phenolic content in the extracts was determined spectroscopically via the Folin-Ciocalteu assay. For the edible plants, high antioxidant activity and high total phenolic content, expressed as Gallic acid equivalents, were found in berries (GAE $>20 \mathrm{mg} / \mathrm{g}$ ), such as aronia and crowberry. Apple extracts (two varieties) also showed strong antioxidant activity, despite low total phenolic contents $(\mathrm{GAE}<12.1 \mathrm{mg} / \mathrm{g})$.

For nonedible plant species, high antioxidant activities were found in willow bark, spruce needles, pine bark, cork, and birch phloem, and in some medicinal plants such as heather, bog-rosemary, willow herb, and meadowsweet. Potato peel and beetroot peel extracts also showed strong antioxidant effects [23]. Natural antioxidants from plants can protect against DNA oxidative damage human lymphocytes induced by hydrogen peroxide, $\mathrm{H}_{2} \mathrm{O}_{2}$. Thus, six herbaceous plants, including Bidens alba (BA), Lycium chinense (LC), Mentha arvensis (MA), Plantago asiatica (PA), Houttuynia cordata (HC), and Centella asiatica (CA) were investigated for their antioxidant activities.

The plants were found to be rich in flavonols, such as myricetinin BA, morin in MA, quercetin in $\mathrm{HC}$, and kaemperol in CA. In addition, polyphenol were abundant in BA and CA. Antioxidant efficacy was determined by the inhibition percentage of conjugated diene formation in a linoleic acid emulsion system and by Trolox-Equivalent Antioxidant Capacity (TEAC) assay.
The acidic methanolic extract of PA, induced the best conjugated diene formation inhibition percentage. For TEAC, the best antioxidant activity was generated from the acidic methanolic extract of HC [24].

Extracts from Brazilian plants, belonging to 16 species of 5 different families (71 extracts) were tested for their antioxidant activities. Ginkgo biloba and rutin, commonly used as antioxidants for medical purposes, were used as standards.

The ethanol extracts of plants belonging to the Verbenaceae family showed lower $\mathrm{EC}_{50}$ values than the other plant extracts. It was found that the more polar partitions (ethyl acetate and n-butanol) are those that generally have higher antioxidant activity [25]

\section{Conclusion}

Plant extracts, fruits and vegetables have indeed shown to possess antioxidant activities. Research needs to be continued for the search of plant with interesting antioxidant effects. In addition, the isolation of known and unknown natural antioxidants will form the platform for novel drug discovery. In this regards, diverse rainforest tropical flora in a diverse ecosystems from Guyana, needs further herbal exploration and commercialization, in addition to their impetus for eco-tourism. Only a couple of reports on the isolation of natural products from two plants suspected to have antioxidant properties have been reported here. Apart from antioxidant drugs, new drugs such as anti-AIDS, anticancer, anti-diabetes, anti-arthritis and anti-alzheimers still awaiting discovery.

\section{References}

1. Jayathilakan K, Sharma GK, Radhakrishna K and Bawa AS. Antioxidant potential of synthetic and natural antioxidants and its effect on warmed-over-flavour in different species of meat (2007) Food Chem 105: 908-916.

https://doi.org/10.1016/j.foodchem.2007.04.068

2. Halliwell B. How to characterize an antioxidant: an update (1905) Bioch Soc Sym 61: 85-91. https://doi.org/10.1042/bss0610073

3. Squadriato GL and Peyor WA. Oxidative Chemistry of nitric oxide: the role of superoxide, peroxynitrite, and carbon dioxide (1998) Free radicals Biol Med 25: 392-403. https://doi.org/10.1016/s0891-5849(98)00095-1

4. Yildrim A, Oktay M and Bilaloglu V.The antioxidant activity of the leaves of Cydonia vulgaris (2001) Turkish J Med Sc 31: 2327.

5. Gulcin I, Oktay M, Kufrevioglu IO and Aslan A. Determination of antioxidant activity of lichen Cetraria islandica (L) (2002) Ach J Ethnopharmacol 79: 325-329.

https://doi.org/10.1016/s0378-8741(01)00396-8

6. Kourounakis AP, Galanakis D, and Tsiakitzis K. Synthesis and pharmacological evaluation of novel derivatives of antiinflammatory drugs with increased antioxidant and antiinflammatory activities (1999) Drug Dev Res 47: 9-16. https://doi.org/10.1002/(sici)1098-2299(199905)47:1<9::aidddr2>3.0.co;2-9

7. Gulcin I, Buyukokuroglu ME, Oktay M and Kufrevioglu IO. On the in vitro antioxidant properties of melatonin (2002) J Pineal Res 33: 167-171. https://doi.org/10.1034/j.1600-079x.2002.20920.x

8. Gulcin I, Buyukokuroglu ME, M. Oktay and I.O. Kufrevioglu. Antioxidant and analgesic activities of turpentine of Pinus nigra Arn. Subsp. Pallsiana (Lamb) (2003) Holmboe J Ethnopharmacol 86: 51-58. https://doi.org/10.1016/s0378-8741(03)00036-9

9. $\quad$ Lu JM, Lin PH, Yao Q and Chen C. Chemical and molecular mechanisms of Antioxidants: Experimental approaches and model systems (2010) J Cell Mol Med (Berl) 14: 840-860. https://doi.org/10.1111/j.1582-4934.2009.00897.x 
10. Jagessar RC and Mohamed N, Antimicrobial activity of selected plants extracts from Guyanas flora (2010) J Pure and Appl Microbio 4: 533-540.

11. Jagessar RC and Allen R. Antimicrobial Potency of the Aqueous Extract of leaves of Terminalia catappa (2011) Aca Res Int 362371. https://doi.org/10.20959/wjpps20179-10010

12. Jagessar RC, Mars A, and Gomathigayam S, Selective Antimicrobial properties of Leaf extract of Samanea Saman against Candida albicans, Staphylococcus aureus and Escherichia coli using several microbial techniques(2011) J American Sci $\quad$ 7: 108-119. http://dx.doi.org/10.13040/IJPSR.0975-8232.4(6).2114-20

13. Jagessar RC, Mars A, Gomes G, Leaf extract of Smilax schomburgkiana exhibit selective antimicrobial properties against pathogenic microorganisms (2009) Life Sci J 6: 76-83.

14. Jagessar RC, Mohammed A and Gomes G, An evaluation of the antibacterial and antifungal activity of leaf extracts of Momordica Charantia against Candida albicans, Staphylococcus aureus and Eschericia Coli (2008) J Nature and Sci 6: 1-14

15. Jagessar RC, Rodriques A, Prasad K, Husain A, Kanhai V,et al,. An investigation of the hypoglycemic effect of the aqueous extract of the fruits of Psidum Guajava, Averrhoa Bilimbi and the peel of Tamarindus indica in Normoglycemic guinea pigs( 2018) WJPPS 7: 77-101. https://doi.org/10.4172/2325-9604-C3-032

16. Jagessar RC, Ramchartar $\mathrm{N}$ and Spencer O. Fruits and Edible Plants, in Fruit and Pomace Extracts: Biological Activity, Potential Applications and Beneficial Health Effects (2015) Jason P. Owen (Ed) Nova Science Publisher, USA.

17. Jagessar RC, Hafeez, Chichester, Crepaul Y. Antimicrobial Activity of the Ethanolic and Aqueous Extract of Passion Fruit (Passiflora edulis Sims), in the absence and presence of $\mathrm{Zn}$ (OAc) $)_{2} .2 \mathrm{H}_{2} \mathrm{O}$ (2017) World J Pharm Pharmaceuti Sci 6: 230-246. https://doi.org/10.20959/wipps20179-10010
18. Jagessar RC and Hope S. Antimicrobial Activity of the Uncombined and Combined Aqueous Extract of Phyllanthus Acidus, Sphagneticola Trilobata Leaves and Doliocarpus Dentatus Bark against Selective Pathogenic Microorganisms in the absence and presence of $\mathrm{Zn}^{2+}$ cations (2016) World J Pharm Pharmaceuti Sci 5: 58-71. https://doi.org/10.4172/2329-6631-C2$\underline{029}$

19. Jagessar RC, Rodrigues A, Prashad K, Husain A, Kanhai V,et al, (2018) An investigation of the hypoglycemic effect of the aqueous extract of the fruits of Psidium Guajava, Averrhoa bilimbi and the peel of Tamarindus indica in normoglycemic guinea pigs (2018) World J Pharm Pharmaceuti Sci 7: 77-101. 10.4172/2325-9604-C3-032

20. Dudonné S, Vitrac X, Coutière P, Woillez M and Mérillon JM. Comparative Study of Antioxidant Properties and Total Phenolic Content of 30 Plant Extracts of Industrial Interest Using DPPH, ABTS, FRAP, SOD, and ORAC Assays (2009) J. Agric. Food Chem 57: 1768-1774. https://doi.org/10.1021/jf803011r

21. Adedapo AA, Jimoh FO, Afolayan AJ and Masika PJ. Antioxidant Properties of the Methanol Extracts of the Leaves and Stems of Celtis Africana (2009) Rec Nat Prod 3: 23-31.

22. Arabshahi DS, Devi DV and Urooj A. Evaluation of antioxidant activity of some plant extracts and their heat, $\mathrm{pH}$ and storage stability (2007) Food Chem 100: 1100-1105. https://doi.org/10.1016/j.foodchem.2005.11.014

23. Kähkönen MP, Hopia AI, Vuorela HJ, Rauha JP, Pihlaja K, et al,. Antioxidant Activity of Plant Extracts Containing Phenolic Compounds (1999) 47: 3954-3962. https://doi.org/10.1021/jf9901461

24. Lin KH, Yang YY, Yang CM, Huang MY, Lo HF, Liu KC, Lin HS, Chao PY. Antioxidant activity of herbaceous plant extracts protect against hydrogenperoxide-induced DNA damage in human lymphocytes (2013), BMC Res Notes 6: 490. https://doi.org/10.1186/1756-0500-6-490

25. Luciana L, Mensor FS, Menezes GG, Leitão AS. Reis T C, et al,. Screening of Brazilian plant extracts for antioxidant activity by the use of DPPH free radical method (2001) 15: 127-130. https://doi.org/10.1002/ptr.687 